\title{
Kekuatan Hukum Jangka Waktu Surat Kuasa Membebankan Hak Tanggungan Kredit Mikro pada Peraturan Menteri Agraria dan Tata Ruang/Kepala Badan Pertanahan Nasional Nomor 22 Tahun 2017
}

\author{
Ahmad Zulfikar ${ }^{1}$ \\ Fakultas Hukum Universitas Batanghari
}

\begin{abstract}
Abstrak. Dalam memberikan kredit, bank harus yakin bahwa dana yang dipinjamkan harus dapat kembali tepat waktu beserta dengan bunganya dan sesuai dengan syarat-syarat yang telah disepakati bersama oleh para pihak yang bersangkutan dalam perjanjian kredit sehingga dalam pelaksanaan perjanjian kredit agar dapat terlaksana secara sehat dan terjamin. Untuk itu, dikeluarkannya Peraturan Menteri Agraria dan Tata Ruang/Badan Pertanahan Nasional Nomor 22 Tahun 2017 dikarenakan kredit mikro saat ini memiliki potensi tinggi dalam penggunaan SKMHT dan menunjukkan bahwa dalam kredit mikro, perbankan sebagai lembaga penyalur dana tetap membutuhkan jaminan dalam pemberian fasilitas kredit sehingga diatur tentang jangka waktu surat kuasa membebankan hak tanggungan sampai dengan berakhirnya kredit pokok. Akan tetapi dengan aturan tersebut membuat surat kuasa membebankan hak tanggungan kredit mikro yang diberikan tidak ditingkatkan pada hak tanggungan, bank selaku kreditor dalam pemberian kredit mikro kepada debitor umumnya tidak menguasai benda yang menjadi jaminan kredit secara fisik, tetapi hanya memiliki hak kebendaan secara administratif. Notaris harus memiliki pengetahuan yang luas mengenai SKMHT agar dapat menyesuaikan klausula SKMHT baik mikro maupun non mikro. Dengan pengetahuan yang mendalam mengenai kuasa, Notaris dapat menanyakan kepada klien. Dalam hal ini Notaris berperan untuk mengarahkan klien dalam isi SKMHT agar tidak bertentangan dengan undang-undang, ketertiban umum dan kesusilaan. Perjanjian harus didasarkan pada konsensus atau kesepakatan dari pihak-pihak yang membuat. Selanjutnya fungsi notaris dalam mencegah jangka waktu surat kuasa membebankan hak tanggungan kredit mikro dapat dilakukan dengan memanfaatkan jabatannya sebagai salah satu penegak hukum dengan memberikan penyuluhan hukum dan kepada perbankan.
\end{abstract}

Kata Kunci : Kekuatan, Hukum, Surat Kuasa Membebankan Hak Tanggungan, Kredit, Mikro

\begin{abstract}
In providing credit, banks must be sure that the loaned funds must be able to be returned on time together with the interest and in accordance with the terms agreed upon jointly by the parties concerned in the credit agreement so that in the implementation of the credit agreement so that it can be carried out in a healthy and secure manner. For this reason, the issuance of Regulation of the Minister of Agrarian Affairs and Spatial Planning/National Land Agency Number 22 Year 2017 is because microcredit currently has high potential in the use of SKMHT and shows that in microcredit, banks as fund channeling institutions still need guarantees in providing credit facilities so that they are regulated regarding the period of the power of attorney to charge the mortgage up to the end of the principal credit. However, with this regulation, the power of attorney imposes a micro credit guarantee given not increased to the mortgage, the bank as the creditor in providing micro credit to the debtor generally does not control the objects which are physical collateral guarantees, but only has administrative rights. The notary must have extensive knowledge about SKMHT in order to adjust the SKMHT clause both micro and non-micro. With in-depth knowledge of power of attorney, the Notary can ask the client. In this case the Notary's role is to direct the client in the contents of SKMHT so as not to conflict with the law, public order and decency. The agreement must be based on consensus or agreement from the parties that made it. Furthermore, the notary's function in preventing the duration of the power of attorney to charge micro credit dependents can be done by utilizing his position as one of law enforcers by providing legal counseling and to banks.
\end{abstract}

Keywords: Strength, Law, Power of Attorney Imposing Mortgage, Credit, Micro

\section{PENDAHULUAN}

Pembangunan nasional khususnya di bidang ekonomi memerlukan perhatian yang serius dari negara melalui pemerintah untuk kepentingan rakyat Indonesia. Dalam hal ini perkembangan kebutuhan dan peningkatannya diperlukan dana yang merupakan salah satu pendukung untuk menggerakkan kegiatan masyarakat di bidang ekonomi. Kebutuhan akan dana atau umumnya dalam dunia perbankan Indonesia disebut kredit terkadang dikaitkan dengan adanya jaminan demi pengamanan pemberian dana atau kredit itu sendiri. Jaminan adalah hal yang penting dalam membuat dan melaksanakan perjanjian kredit atau perjanjian pinjam meminjam uang serta melindungi kepentingan para pihak khususnya kreditor. ${ }^{2}$

\footnotetext{
${ }^{1}$ Dosen Fakultas Hukum Universitas Batanghari

${ }^{2}$ Randy Putra Tama, Keberlakuan Surat Kuasa Membebankan Hak Tanggungan Yang Telah Habis Jangka Waktu,( Jurnal Hukum Program Studi Magister Kenotariatan Universitas Sriwijaya, 2016), hal 3.
} 
Mengingat pentingnya dana perkreditan tersebut dalam proses pembangunan, sudah semestinya jika pemberi dan penerima kredit serta pihak lain yang terkait mendapat perlindungan melalui suatu lembaga hak jaminan yang kuat dan yang dapat memberikan kepastian hukum bagi semua pihak yang berkepentingan. ${ }^{3}$ Dalam memberikan kredit, bank harus yakin bahwa dana yang dipinjamkan harus dapat kembali tepat waktu beserta dengan bunganya dan sesuai dengan syarat-syarat yang telah disepakati bersama oleh para pihak yang bersangkutan dalam perjanjian kredit sehingga dalam pelaksanaan perjanjian kredit agar dapat terlaksana secara sehat dan terjamin.

Hal ini dimaksudkan sebagai solusi hukum untuk memberikan kepastian pengembalian pinjaman tersebut. Dalam praktek jaminan yang sering digunakan adalah jaminan kebendaan yaitu berupa tanah, atau yang disebut dengan jaminan hak tanggungan. Hak tanggungan merupakan lembaga hak jaminan yang kuat atas benda tidak bergerak berupa tanah yang dijadikan jaminan, karena memberikan kedudukan yang lebih tinggi bagi kreditur pemegang hak tanggungan dibandingkan dengan kreditur lainnya. ${ }^{4}$

Memberikan Hak Tanggungan, pemberi Hak Tanggungan wajib hadir dihadapan notaris. Notaris/pejabat pembuat akta tanah adalah pejabat umum yang berprofesi membuat akta pendirian dan anggaran dasar suatu badan hukum maupun badan usaha sehingga notaris mengetahui betul organ badan hukum mana yang berwenang mewakili badan hukum maupun badan usaha ketika mengikatkan diri dalam Surat Kuasa Membebankan Hak Tanggungan (SKMHT) yang kemudian ditindaklanjuti dengan APHT. Dengan demikian, surat kuasa membebankan hak tanggungan yang telah diterima pejabat pembuat akta tanah menjadi akta pemberian hak tanggungan maupun akta pemberian hak tanggungan yang telah diterima kantor pertanahan menjadi Sertifikat Hak Tanggungan (SHT), merupakan bukti otentik yang tidak perlu diragukan lagi kekuatan pembuktiannya. ${ }^{5}$

Menurut penulis dilihat dari jangka waktunya, Surat Kuasa Membebankan Hak Tanggungan (SKMHT) terbagi atas 3 macam:

1. Surat Kuasa Membebankan Hak Tanggungan berlaku 1 (satu) bulan yang dibuat dikarenakan pemegang jaminan/kreditor berhalangan hadir dan/atau dikarenakan alasan lain.

2. Surat Kuasa Membebankan Hak Tanggungan berlaku 3 (tiga) bulan yang dibuat dikarenakan jaminan yang dijaminkan sedang diproses pendaftaran atau balik nama kepada penjamin dikarenakan jual beli.

3. Surat Kuasa Membebankan Hak Tanggungan berlaku sampai dengan berakhirnya perjanjian pokok yang dibuat guna penjaminan kredit mikro yang diatur oleh Keputusan Menteri Agraria dan Tata Ruang/Badan Pertanahan Nasional Nomor 22 Tahun 2017.

Mengenai SKMHT pada bagian 1 (pertama) dan 2 (kedua) menurut penulis ialah Surat Kuasa Membebankan Hak Tanggungan yang akan segera diproses pendaftaran Hak Tanggungan dan Surat Kuasa Membebankan Hak Tanggungan bagian 3 (ketiga) adalah Surat Kuasa Membebankan Hak Tanggungan yang pendaftaran hak tanggungannya dilakukan jika dilihat dari terjadi wanprestasi atau tidaknya.

Kemudian berdasarkan Keputusan Menteri Agraria dan Tata Ruang/Badan Pertanahan Nasional Nomor 22 Tahun 2017, menurut penulis kredit mikro adalah kredit yang diberikan perbankan kepada nasabah/debitur yang diperuntukkan pada usaha mikro dan kepemilikan rumah berdasarkan luas tertentu dan kredit lain yang besarnya jumlah kredit sampai dengan Rp. 200.000.000,- (dua ratus juta rupiah).

Menurut M.Khoidin, bahwa pelaksanaan jaminan atas tanah selama ini telah terjadi hal-hal yang tidak mendukung keberadaan suatu lembaga hak jaminan yang kuat karena terjadi dalam praktek seolah-olah melembagakan SKMHT tersebut. ${ }^{6}$ Sedangkan Konsumen paling besar yang menggunakan surat kuasa membebankan hak tanggungan (SKMHT) adalah perbankan yang berkedudukan sebagai kreditur, tidak dapat dibayangkan jika ternyata ada debitur yang mengetahui dan memahami kedudukan jangka waktu surat kuasa membebankan hak tanggungan (SKMHT) kredit mikro dan sudah tentu peluang seperti ini terbuka lebar untuk dilakukan oleh debitur, tentu jika hal ini terjadi akan menimbulkan ketidakpercayaan dari klien terhadap kualitas akta yang dibuat oleh Notaris dan/atau pejabat pembuat akta tanah (PPAT).

3 Adrian Sutedi, Hukum Hak Tanggungan, (Jakarta : Sinar Grafika, 2012), hal 93-94.

4 Algadita F.R.S, Analisis Yuridis Penggunaan Surat Kuasa Membebankan Hak Tanggungan Bagi Kreditur Dalam Menangani Debitur Wanprestasi, (Jurnal Private Law, 2014), hal 14.

${ }^{5}$ Hery Shietra, Praktik Hukum Jaminan Kebendaan, (Bandung: Citra Aditya Bakti, 2016), hal 71.

${ }^{6}$ M. Khoidin, Dimensi Hukum Hak Tanggungan Atas Tanah, (Yogyakarta: LaksBang, 2006), hal 16. 
Dikeluarkannya Peraturan Menteri Agraria dan Tata Ruang/Badan Pertanahan Nasional Nomor 22 Tahun 2017 dikarenakan kredit mikro saat ini memiliki potensi tinggi dalam penggunaan SKMHT dan menunjukkan bahwa dalam kredit mikro, perbankan sebagai lembaga penyalur dana tetap membutuhkan jaminan dalam pemberian fasilitas kredit sehingga diatur tentang jangka waktu surat kuasa membebankan hak tanggungan sampai dengan berakhirnya kredit pokok. Akan tetapi dengan aturan tersebut membuat surat kuasa membebankan hak tanggungan kredit mikro yang diberikan tidak ditingkatkan pada hak tanggungan, bank selaku kreditor dalam pemberian kredit mikro kepada debitor umumnya tidak menguasai benda yang menjadi jaminan kredit secara fisik, tetapi hanya memiliki hak kebendaan secara administratif.

Pengikatan obyek jaminan yang berupa tanah, yaitu Hak Milik, Hak Guna Bangunan dan Hak Guna Usaha, prosesnya hanya sampai dengan Surat Kuasa Membebankan Hak Tanggungan (SKMHT) saja, dengan tidak dibebankan Hak Tanggungan atas obyek jaminan tersebut, maka kreditur belum memiliki hak kebendaan atas jaminan tersebut secara faktual, sebab kepastian hukum kreditur sebagai kreditur preferen terletak pada hak tanggungan, dan sebagai fungsinya SKMHT hanya lah kuasa yang diberikan debitur atau pemilik jaminan kepada kreditur, untuk ditingkatkan pada hak tanggungan.

Kelemahan atas Surat Kuasa Membebankan Hak Tanggungan (SKMHT) kredit mikro ini tidak dapat dihindarkan, namun tetap digunakan. Kedepannya tidak dapat dipungkiri akan terjadi suatu permasalahan hukum atas penggunaanya. Sehingga menimbulkan pertanyaan bagi penulis sendiri, apa yang menjadi tujuan dikeluarkannya Permen Nomor 22 Tahun 2017 itu, apakah Permen itu dapat mejadi hambatan untuk menyalurkan pemberian kredit mikro, jika tujuan Permen itu untuk memberikan kemudahan debitur kredit mikro mendapatkan pinjaman dari perbankan, kenapa di dalam Permen tidak mengatur tentang bea pendaftaran hak tanggungan khusus untuk kredit mikro saja.

Berdasarkan uraian di atas penulis tertarik mencari jawaban atas permasalahan dalam surat kuasa membebankan hak tanggungan kredit mikro yang diatur dalam Peraturan Menteri Agraria dan Tata Ruang/Kepala Badan Pertanahan Nasional Nomor 22 Tahun 2017.

Berdasarkan uraian yang terdapat pada latar belakang di atas, maka penulis akan membatasi permasalahan yang akan dibahas dalam penelitian ini sebagai berikut :

1. Bagaimana kekuatan hukum surat kuasa membebankan hak tanggungan kredit mikro?

2. Bagaimana fungsi notaris memberikan kepastian hukum pada para pihak dalam surat kuasa membebankan hak tanggungan kredit mikro?

Kemudian tujuan dari penelitian ini sendiri yaitu untuk menganalisis kekuatan hukum surat kuasa membebankan hak tanggungan kredit mikro dan Untuk mengetahui fungsi notaris memberikan kepastian hukum pada para pihak dalam surat kuasa membebankan hak tanggungan kredit mikro.

\section{METODE PENELITIAN}

Metode penelitian merupakan uraian teknis yang digunakan dalam penelitian. ${ }^{7}$ Adapun metode penelitian yang digunakan dalam penelitian ini adalah sebagai berikut :

1. Metode pendekatan

Peter Mahmud Marzuki menyatakan ada empat pendekatan dalam penelitian hukum, yaitu pendekatan undang-undang (statute approach), pendekatan kasus (case approach), pendekatan historis (historical approach), dan pendekatan konseptual (conceptual approach). ${ }^{8}$

Dilihat dari isu hukum yang diangkat dalam penelitian ini, yaitu mengenai Jangka Waktu Surat Kuasa Membebankan Hak Tanggungan Kredit Mikro, maka pendekatan yang digunakan dalam penelitian ini adalah pendekatan undang-undang (statute approach) dan Pendekatan Konseptual (conseptual approach). Pendekatan undang-undang (statute approach) dilakukan dengan menelaah semua undangundang dan regulasi yang bersangkut paut dengan isu hukum yang ditangani. Pendekatan Konseptual (conseptual approach) dilakukan dengan memahami pandangan-pandangan dan doktrin-doktrin di dalam ilmu hukum berkaitan tentang surat kuasa membebankan hak tanggungan kredit mikro yakni "penelitian terhadap konsep-konsep hukum seperti sumber hukum, fungsi hukum, lembaga hukum dan sebagainya. ${ }^{9}$

\footnotetext{
${ }^{7}$ Bahder Johan Nasution, Metode Penelitian Ilmu Hukum, (Bandung : CV. Mandar Maju, 2016), hal 3.

${ }^{8}$ Peter Mahmud Marzuki, Penelitian Hukum, (Jakarta : Kencana, 2006), hal 93.

9 Bahder Johan Nasution, Metode Penelitian Ilmu Hukum, (Bandung: Mandar Maju, 2008), hal 1.
} 
Dengan mempelajari pandangan-pandangan dan dokterin-dokterin di dalam ilmu hukum, penulis akan menemukan ide-ide yang melahirkan pengertian-pengertian hukum, konsep-konsep hukum, dan asas-asas hukum relevan dengan isu yang dihadapi. Pemahaman akan pandangan-pandangan dan dokterin-dokterin tersebut merupakan sandaran bagi peneliti dalam membangun suatu argumentasi hukum dalam memecahkan isu hukum yang dihadapi.

2. Rancangan kegiatan

Penelitian ini merupakan penelitian yuridis normatif. Dalam penelitian yuridis normatif, dilakukan terhadap kaidah-kaidah hukum yang merupakan patokan-patokan berperilaku atau bersikap tidak pantas. Penelitian tersebut dapat dilakukan (terutama) terhadap bahan hukum primer dan sekunder, sepanjang bahan-bahan tadi mengandung kaidah-kaidah hukum. ${ }^{10}$

Maksudnya ialah bahwa tinjauannya itu berangkat dan memfokuskan diri, pada ketentuan hukum positif tata hukum yang menguasai perkara atau isu hukum yang bersangkutan. Artinya berada dalam kerangka kemauan dan maksud dari tata hukum yang bersangkutan. Untuk melihat sistem normatif dari ilmu hukum harus dipahami terlebih dahulu ciri-ciri atau karakter ilmu hukum normatif tersebut. ${ }^{11}$

Dengan demikian, dalam penelitian penelitian hukum normatif ini sudah jelas bahwa rancangan kegiatan yang dilakukan oleh peneliti adalah menganalisis kekuatan hukum jangka waktu surat kuasa membebankan hak tanggungan kredit mikro pada Peraturan Menteri Agraria Dan Tata Ruang/Kepala Badan Pertanahan Nasional Nomor 22 Tahun 2017.

3. Bahan dan alat utama

Bahan-bahan hukum yang akan digunakan dalam penelitian kepustakaan ini antara lain adalah :

a. Bahan hukum primer

Bahan hukum primer adalah bahan-bahan hukum yang dijadikan dasar dalam menyusun penulisan tesis yang diambil dari kepustakaan, diantaranya :

1) Undang-Undang Dasar Negara Kesatuan Republik Indonesia 1945;

2) Kitab Undang-Undang Hukum Perdata;

3) Undang-undang nomor 5 Tahun 1960 Tentang Peraturan Dasar Pokok-Pokok Agraria;

4) Undang-undang Nomor 4 Tahun 1996 Tentang Hak Tanggungan;

5) Undang-undang Nomor 2 tahun 2014 tentang perubahan atas undang-undang Nomor 30 Tahun 2004 tentang Jabatan Notaris.

6) Peraturan Menteri Agraria dan Tata Ruang/Kepala Badan Pertanahan Nasional Nomor 22 Tahun 2017.

7) Peraturan lain yang relavan dengan penelitian.

b. Bahan hukum sekunder

1) Buku-buku literatur yang relevan dengan judul tesis ini.

2) Makalah-makalah tentang Hukum Perjanjian/Kontrak, Perbankan, Agraria, surat kuasa membebankan hak tanggungan.

c. Bahan tersier

Bahan hukum tersier adalah bahan hukum yang akan digunakan penulis dalam mendukung bahan hukum sekunder, yakni :

1) Kamus Hukum (Black's Law Dictionary).

2) Kamus Besar Bahasa Indonesia.

3) Ensiklopedia.

Dengan demikian, sumber bahan pustaka atau data sekunder dalam penelitian hukum normatif ini adalah menganalisis terhadap Peraturan Menteri Agraria Dan Tata Ruang/Kepala Badan Pertanahan Nasional Nomor 22 Tahun 2017 sedangkan alat utama dalam penelitian hukum normatif ini adalah bahan hukum primer dan bahan hukum tersier.

${ }^{10}$ Soerjono Soekanto dan Sri Mamudji, Penelitian Hukum Normatif Suatu Tinjauan Singkat, (Jakarta: Rajawali Pers, 2008), hal 62.

${ }^{11}$ Bahder Johan Nasution, Op.Cit, hal. 91 
4. Teknik pengumpulan data

Pengumpulan data dalam penelitian hukum normatif terdapat 3 (tiga) jenis metode pengumpulan data sekunder, yaitu studi pustaka, dokumen dan studi arsip. ${ }^{12}$ Pengertian dokumen menurut Poerwadarminta adalah sesuatu yang tertulis atau tercetak, yang dapat dipakai sebagai bukti atau keterangan. ${ }^{13}$ Dengan demikian, teknik pengumpulan data dalam penelitian hukum normatif ini adalah menggunakan dokumen yang berkaitan dengan Peraturan Menteri Agraria dan Tata Ruang/Kepala Badan Pertanahan Nasional Nomor 22 Tahun 2017.

5. Teknik analisis

Analisis data yang digunakan dalam penelitian hukum normatif adalah analisis kualitatif, yakni analisis data dengan cara menguraikan data secara bermutu dalam bentuk kalimat yang teratur, runtun, logis dan efektif sehingga memudahkan interprestasi data dan pemahaman hasil analisis. ${ }^{14}$ Oleh karena itu, teknik analisis dalam penelitian hukum normatif ini adalah menguraikan hasil dari analisis dalam bentuk kalimat tentang kekuatan hukum jangka waktu surat kuasa membebankan hak tanggungan kredit mikro pada Peraturan Menteri Agraria Dan Tata Ruang/Kepala Badan Pertanahan Nasional Nomor 22 Tahun 2017.

\section{HASIL DAN PEMBAHASAN}

\section{Kekuatan Hukum Surat Kuasa Membebankan Hak Tanggungan Kredit Mikro}

Surat Kuasa adalah salah satu bentuk dari perjanjian yang mana dapat diartikan sebagai Suatu perbuatan dengan mana satu orang atau lebih mengikatkan dirinya terhadap satu orang lain atau lebih, berdasarkan Pasal 13 KUH Perdata.

Notaris harus memiliki pengetahuan yang luas mengenai SKMHT agar dapat menyesuaikan klausula SKMHT baik mikro maupun non mikro. Dengan pengetahuan yang mendalam mengenai kuasa, Notaris dapat menanyakan kepada klien mengenai :

1. Ruang lingkup mengenai kuasa yang akan dibuat.

2. Data-data apa saja yang ada yang dimiliki oleh klien (para pihak), demikian juga semua peraturan yang terkait dengan materi dan substansi kuasa tersebut.

3. Semua data, peraturan, semua yang terkait dengan ruang lingkup surat kuasa membebankan hak tanggungan (SKMHT) yang dimintakan untuk dibuat.

4. Hak-hak dan kewajiban-kewajiban apa saja yang minta dirumuskan dalam SKMHT meskipun bentuk SKMHT telah baku.

Dalam pembuatan SKMHT, Notaris perlu membangun struktur akta dan menyusun sebuah akta Notaris sesuai anatomi akta, ada beberapa hal yang dapat dijadikan dasar untuk membangun struktur akta Notaris, antara lain :

1) Latar belakang yang akan diperjanjikan.

2) Identifikasi para pihak (subjek hukum).

3) Identifikasi objek yang akan diperjanjikan.

4) Membuat kerangka akta.

5) Merumuskan substansi akta.

6) Kedudukan para pihak

7) Batasan-batasan (yang boleh atau tidak diperbolehkan) menurut aturan hukum.

8) Hal-hal yang dibatasi dalam pelaksanannya.

9) Pilihan hukum dan pilihan pengadilan.

10) Klausula penyelesaian sengketa.

11) Kaitannya dengan akta yang lain (jika ada). ${ }^{15}$

\footnotetext{
${ }^{12}$ Ishaq, Metode Penelitian Hukum Dan Penulisan Skripsi, Tesis Serta Disertasi, (Bandung: Alfabeta, 2017), hal 69.

${ }^{13}$ Bahder Johan Nasution, Op.Cit, hal 104.

${ }^{14}$ Ishaq, Op.Cit, halaman 69.

15 Mulyoto, Perjanjian; Tehnik Cara Membuat Dan Hukum Perjanjian Yang Harus Dikuasai, (Yogyakarta: Cakrawala
} Media, 2012), hal 37-38. 
Dalam hal ini Notaris berperan untuk mengarahkan klien dalam isi SKMHT agar tidak bertentangan dengan undang-undang, ketertiban umum, dan kesusilaan. Perjanjian harus didasarkan pada konsensus atau kesepakatan dari pihak-pihak yang membuat. Dengan asas konsensualisme, perjanjian dikatakan telah lahir jika ada kata sepakat atau persesuaian kehendak diantara para pihak yang membuat perjanjian tersebut.

Notaris dalam membuat akta perjanjian notariil harus jujur, cermat, teliti, tidak memihak salah satu pihak dan memahami semua peraturan yang berhubungan dengan akta yang akan dibuatnya. Adapun larangan-larangan dalam membuat perjanjian bagi Notaris. ${ }^{16}$ Larangan bagi Notaris dalam membuat perjanjian:

a. Notaris dilarang membuat akta perjanjian yang memihak kepada salah satu pihak.

b. Notaris dilarang membuat akta perjanjian yang bertentangan dengan akta yang dibuat sebelumnya.

c. Notaris dilarang membuat akta pencabutan perjanjian pemberian kuasa secara sepihak dimana akta pemberian kuasa tersebut telah ditanda tangani oleh kedua belah pihak (pemberi kuasa dan penerima kuasa).

d. Notaris dilarang memberitahukan isi (segala sesuatu mengenai akta yang dibuatnya) dan segala keterangan yang diperolehnya guna pembuatan akta.

e. Notaris dilarang untuk tidak membacakan isi akta kepada para pihak, kecuali para pihak sudah membacanya sendiri, mengerti dan menyetujui, hal demikian sebagaimana dinyatakan dalam penutup akta dan tiap halaman diparaf oleh para pihak/para penghadap, para saksi dan Notaris sedangkan halaman terakhir ditanda tangani para pihak, para saksi dan Notaris.

f. Notaris dilarang membuat akta perjanjian yang bertentangan dengan UU, ketertiban umum dan/atau kesusilaan.

g. Notaris dilarang membuat akta simulasi (bohongan) lebih-lebih dalam hal untuk tujuan yang bertentangan dengan UU. ${ }^{17}$

Notaris harus memperhatikan perwakilan dalam perjanjian. Perwakilan demi hukum tidak dibenarkan untuk disubtitusikan, lembaga perwakilan dalam hukum privat dibedakan menjadi 3 (tiga) yaitu:

1) Perwakilan menjadi kontraktual yaitu perwakilan karena adanya pemberian kuasa, diatur dalampasal 1792 sampai dengan 1819 KUHPerdata.

2) Perwakilan organic, yaitu seseorang yang berkedudukan di salah satu organ badan hukum mewakili badan hukum tersebut.

3) Perwakilan demi hukum, yaitu seseorang yang karena kedudukannya sebagai misal: dalam kedudukannya selaku orang tua mewakili anaknya yang masih dibawah umur atau suami dan istri salah satu meninggal dunia maka suami/istri yang hidup lebih lama (masih hidup), maka demi hukum menjadi wali dari anak kandungnya tersebut. ${ }^{18}$

Dalam pembuatan akta perjanjian notariil agar diusahakan di dalam pembuatannya mengandung unsur kelengkapan, kebenaran, kejelasan dan keabsahan. Maksudnya adalah:

1) Mengandung unsur kejelasan artinya:

- Mulai dari judul akta harus mengandung/mencerminkan secara garis besar substansi dari isi akta.

- Redaksi setiap pasal tidak boleh berwayuh arti atau mempunyai arti lebih dari satu arti/bisa ditafsirkan lain.

- Jangan berpindah ke pasal yang lain sebelum tuntas terkait redaksi pasal tersebut.

- Memuat secara detail segala sesuatu yang memang harus diatur dalam akta/perjanjian tersebut.

2) Mengandung unsur kebenaran :

- Usahakan sepanjang dimungkinkan mengupayakan kebenaran material. Hal demikian bisa diupayakan dengan pemberian nasehat hukum kepada para penghadap terkait dengan akta yang akan dibuat dan dikemukakan akibat hukum dan sanksi dalam hal tidak mengemukakan atau menyampaikan segala sesuatu selain daripada yang sebenarnya. ${ }^{19}$
16 Ibid.
${ }^{17}$ Ibid.
18 Ibid.
${ }^{19}$ Subekti, Perjanjian; Hukum Perjanjian, (Jakarta : Intermasa, 1990), hal 26. 
Mengenai kebatalan dan pembatalan perikatan-perikatan diatur dalam Buku III, Bagian kedelapan, Bab IV (Pasal 1446-Pasal 1456 KUHPerdata). Bagian ini hanya secara sumier mengatur sebagian dari kebatalan, khususnya perjanjian yang dilakukan oleh mereka yang tidak cakap, yaitu mereka yang dibawah umur, ditaruh dibawah curatele, serta cacat dalam kehendak. Cacat dalam kehendak terjadi karena adanya paksaan, kekeliruan, tipuan dan penyalahgunaan keadaan. ${ }^{20}$

Kebatalan suatu perjanjian dibedakan antara:

1. Dapat dibatalkan, dalam hal tidak dipenuhinya syarat subyektif yaitu :

- Tidak adanya kata sepakat, dan

- Tidak adanya kecakapan bertindak dan

- Pihak-pihak yang membuat perjanjian.

2. Batal demi hukum, dalam hal tidak dipenuhinya syarat obyektif, yaitu:

- Tidak ada causa/obyek perjanjian

- Tidak mengandung causa yang dibenarkan menurut hukum.

3. Batal demi hukum karena Non existent, yaitu disebabkan karena:

- Tiadanya sesuatu yang esensi/pokok dalam perjanjian tersebut.

- Tiada dipenuhinya syarat yang diharuskan oleh UU sebagai contoh: PT, Yayasan didirikan tidak dengan akta Notaris (tidak notariil). ${ }^{21}$

Notaris harus jujur, mandiri, cermat, dan tidak memihak serta harus mengikuti semua peraturan tidak terbatas peraturan jabatan Notaris tetapi juga semua peraturan yang ada hubungannya dengan akta yang akan dibuat. Dalam menyusun klausula agar dalam penyusunan klausula dari segi legal benar-benar aman dan kuat, diusahakan menyusun klausula sedetail mungkin agar dikemudian hari jika timbul sengketa dapat ditekan sekecil mungkin bahkan dihindari.

\section{Fungsi Notaris Memberikan Kepastian Hukum Pada Para Pihak Dalam Surat Kuasa Membebankan Hak Tanggungan Kredit Mikro}

Peran Notaris dalam sektor pelayanan jasa adalah sebagai pejabat yang diberi wewenang oleh negara untuk melayani masyarakat dalam bidang perdata khususnya pembuatan akta otentik dan kewenangan lainya. Sebagaimana disebutkan dalam Pasal 1 ayat (1) Undang-undang Nomor 2 Tahun 2014 tentang Jabatan Notaris.

Selanjutnya pengertian berwenang yaitu meliputi : Berwenang terhadap orangnya, yaitu untuk kepentingan siapa akta itu dibuat atau dikehendaki oleh yang berkepentingan. Berwenang terhadap akta nya, yaitu yang berwenang membuat suatu akta otentik mengenai semua perbuatan, perjanjian dan ketetapan yang diharuskan oleh undang-undang atau yang dikehendaki oleh yang bersangkutan. Serta wewenang terhadap waktu dan tempat pembuatan akta otentik, yaitu sesuai tempat kedudukan dan wilayah jabatan Notaris dan Notaris menjamin kepastian waktu para penghadap yang tercantum dalam akta. ${ }^{22}$

Kewenangan Notaris telah diatur dalam Undang-Undang Nomor 2 Tahun 2014 perubahan atas Undang- Undang Nomor 30 Tahun 2004 tentang Jabatan Notaris, dalam Pasal 15 ayat (1) tentang kewenangan seorang Notaris yaitu Notaris berwenang membuat akta otentik mengenai semua perbuatan, perjanjian, dan penetapan yang diharuskan oleh peraturan perundang-undangan dan/atau yang dikehendaki oleh yang berkepentingan untuk dinyatakan dalam akta autentik, menjamin kepastian tanggal pembuatan akta, menyimpan akta, memberikan grosse, salinan dan kutipan akta.

Akta otentik yang dibuat oleh Notaris tak jarang dipermasalahkan oleh salah satu pihak atau oleh pihak lain karena dianggap merugikan kepentingannya, sehubungan dengan akta yang telah dibuat. Terkait dengan hal tersebut pada akta surat kuasa membebankan hak tanggungan terutama pada kredit mikro, notaris berwenang mengenai semua perbuatan atau segala penetapan klausul pada akta yang dapat memberikan kepastian hukum pada para pihak.

Notaris sebagai officium nobile atau profesi yang terhormat di bidang hukum tentu dibutuhkan penguasaan materi akan bidang hukum perdata yang mumpuni dalam rangka memenuhi kebutuhan

\footnotetext{
${ }^{20}$ Habib Adjie, Kebatalan dan Pembatalan Akta Notaris, (Bandung: PT. Refika Aditama, 2011), hal 4.

${ }^{21}$ Mulyoto, Op.Cit, hal 44-45.

${ }^{22}$ Habib Adjie, Meneropong Khasanah Notaris dan PPAT Indonesia, (Bandung: PT. Citra Aditya Bakti, 2009$)$, hal 14.
} 
masyarakat akan jasa hukum di bidang pembuatan alat bukti. ${ }^{23}$ Perkembangan hukum yang sangat cepat tentu mempengaruhi tugas yang dijalankan oleh notaris untuk membuat akta-akta dalam rangka mengikuti perkembangan yang begitu cepat.

Dasar perbuatan atau tugas notaris sudah sangat jelas diatur dalam Undang-undang Nomor 2 tahun 2014 tentang Jabatan Notaris, akan tetapi tidak semuanya perbuatan atau tugas notaris tersebut telah memenuhi tuntutan para pihak akan pemenuhan kebutuhan jasa di bidang hukum dalam pembuatan aktaakta karena begitu cepatnya perkembangan hukum di masyarakat, maka notaris dituntut dapat menemukan cara atau klausul pada aktanya, yang dapat dikategorikan sebagai penemuan hukum.

Menurut penulis penemuan klasul akta dapat juga diartikan sebagai penemuan hukum yang mana penemuan hukum dapat diartikan sebagai pembentukan hukum oleh hakim atau penegak hukum lainnya (dalam hal ini notaris). Rechtsviding atau Law Making yang menemukan hukum tidak hanya hakim tetapi juga notaris. ${ }^{24}$ Sebab notaris akan berhadapan dengan peristiwa konkrit yang masih baru untuk dipecahkan atau dirumuskan menjadi peristiwa hukum dalam pembuatan akta otentik. notaris sama saja menemukan hukum jika klausul pada aktanya dapat memberikan apa yang dikehendaki kliennya dan dapat memberikan perlindungan hukum walaupun belum ada aturan khusus yang mengaturnya dengan tidak bertentangan dengan undang-undang yang berlaku.

Pada aturannya tidak ada aturan jelas tentang kewajiban notaris dalam menemukan hukum atau menemukan klausul akta baru, tetapi sebagai pengembang profesi hukum notaris juga mempunyai tanggung jawab atas mutu pelayanan profesinya, seseorang yang menyandang profesi hukum haruslah orang yang dapat dipercaya secara penuh dan ia tidak akan menyalahgunakan situasi dan kondisi yang ada. ${ }^{25}$

Sehingga penulis mengacu pada Pasal 15 ayat (1) Undang-Undang Jabatan Notaris menegaskan kewenangan notaris membuat akta secara umum, dengan batasan :

1. Tidak dikecualikan kepada pejabat lain yang ditetapkan oleh undang-undang.

2. Menyangkut akta yang harus dibuat atau berwenang membuat akta otentik mengenai semua perbuatan, perjanjian, dan ketetapan yang diharuskan oleh aturan hukum atau dikehendaki oleh yang berkepentingan.

3. Mengenai subjek hukum (orang atau badan hukum) untuk kepentingan siapa akta itu dibuat atau dikehendaki oleh yang berkepentingan. Notaris membuat akta untuk setiap orang, tetapi agar menjaga netralitas notaris dalam pembuatan akta, ada batasan yang ditentukan dalam Pasal 16 UUJN.

4. Berwenang mengenai tempat, di mana akta itu dibuat, hal ini sesuai dengan tempat kedudukan dan wilayah jabatan notaris.

5. Mengenai waktu pembuatan akta, dalam hal ini notaris harus menjamin kepastian waktu menghadap para penghadap yang tercantum dalam akta.

Sehingga aturan ini menurut penulis yang menjadi acuan terhadap fungsi notaris dalam menemukan klasul-klausul baru dalam aktanya jika aturan yang ada dirasa kurang memberikan kepastian hukum dalam akta tersebut. Dalam prakteknya notaris juga lebih banyak membuat akta dalam bentuk akta baku yang bentuknya sudah ditentukan oleh pemerintah di dalam undang-undang, namun pada saat-saat tertentu, notaris juga dituntut untuk dapat melakukan penemuan hukum, dalam perjanjian atau kontrak tertentu karena ketidaksempurnaan hukum yang tersedia.

Dalam melakukan penemuan hukum, Notaris dituntut sebuah tanggung jawab yang ditegaskan dalam pasal 16 Undang-Undang Jabatan Notaris mengenai sikap netral yang harus diambil oleh seorang Notaris. seorang Notaris dalam membuat keputusan dan mencanangkan pasal-pasal dalam aktanya harus dapat melakukan tugasnya itu dengan tidak berpihak pada salah satu kepentingan klien saja.

Dalam melaksanakan profesinya haruslah dilakukan secara bermatabat, karena tugas profesi merupakan tugas kemasyarakatan yang berhubungan langsung dengan nilai-nilai dasar yang merupakan harkat dan martabat. Oleh karena itu pelayanan profesi hukum memerlukan pengawasan dari masyarakat,

${ }^{23}$ Asep Setiawan, Analisis Yuridis Standar Prosedur Pelayanan Operasional (SPPOP) Notaris Dalam Pembuatan Akta Terkait Klausul Proteksi Diri Notaris Berdasarkan Pasal 15 AYAT (1) Undang-Undang Nomor 2 Tahun 2014 Tentang Jabatan Notaris, Jurnal Akta Vol. 4, No. 1, 2017, hal 6.

${ }^{24}$ Achmad Sulchan, https://www.slideshare.net/FredyBagusKusumaningYandi/teori-hukum-dan-penemuan-hukum-notarisdr-achmad-sulchan, diakses pada tanggal 9 Juni 2019.

${ }^{25}$ Abu Jusuf, Etika Jabatan Notaris Sebagai Profesi Hukum, Media Notariat, Nomor 2, 1999, hal 72. 
namun menurut kebiasaan masyarakat tidak mempunyai kompetisi teknik untuk mengukur dan mengawasi para profesional tersebut. Alasannya karena tak seorangpun dari anggota masyarakat yang terlepas dari permasalahan hukum dan tentunya harus pula berhadapan dengan penyandang profesi hukum. ${ }^{26}$

Jabatan notaris tidak ditempatkan di lembaga yudikatif, eksekutif ataupun yudikatif. Notaris diharapkan memiliki posisi netral, sehingga apabila ditempatkan di salah satu dari ketiga badan negara tersebut maka notaris tidak lagi dapat dianggap netral. Dengan posisi netral, notaris diharapkan untuk memberikan penemuan dalam klausul akta dan atas tindakan hukum yang dilakukan notaris atas permintaan kliennya. Dalam hal melakukan tindakan hukum untuk kliennya, notaris juga tidak boleh memihak kliennya, karena tugas notaris ialah untuk mencegah terjadinya masalah.

Menurut Yahya Harahap, notaris memiliki kewenangan untuk Mengkonstantir atau menentukan apa yang terjadi di hadapan matanya, Oleh karena itu, dia berhak mengkonstantir atau menentukan fakta yang diperolehnya guna meluruskan isi akta yang lebih layak. ${ }^{27}$

Seperti sebelumnya yang dikemukakan $\mathrm{CH}$. Gatot Wardoyo tentang beberapa klausula yang selalu dan perlu dicantumkan dalam perjanjian kredit, menurut penulis dapat juga diterapkan atau ditambahkan oleh notaris dalam klausul SKMHT pada kredit mikro guna melindungi kepentingan para pihak terutama kreditur, yaitu :

1. Klausula mengenai tindakan yang dilarang oleh bank (negative clause) klausula ini terdiri atas berbagai macam hal yang mempunyai akibat yuridis dan ekonomi bagi pengamanan kepentingan bank sebagai tujuan umum.

2. Tigger clause atau opeinsbaar clause. Klausula ini mengatur hak bank untuk mengakhiri perjanjian secara sepihak walaupun jangka waktu perjanjian tersebut belum berakhir.

3. Klausula ketaatan pada ketentuan bank. Klausula ini dimaksudkan untuk menjaga kemungkinan bila terdapat hal-hal yang tidak diperjanjikan secara khsusus tetapi dipandang perlu, maka sudah dianggap telah diperjanjikan secara umum.

Sehingga jika aturan yang ada seperti pada Peraturan Menteri Agraria dan Tata Ruang/Kepala Badan Pertanahan Nasional Nomor 8 Tahun 2012 tentang bentuk surat kuasa membebankan hak tanggungan, yang dirasa klausul tersebut tidak sesuai dengan surat kuasa membebankan hak tanggungan kredit mikro, notaris sebagai pejabat yang berwenang dapat menggunakan kewajibannya untuk memberikan kepastian hukum kepada para pihak dengan menemukan klausul yang tepat digunakan pada surat kuasa membebankan hak tanggungan kredit mikro.

\section{KESIMPULAN}

Berdasarkan uraian yang telah dijelaskan dalam pembahasan, maka penulis dapat mengambil kesimpulan sebagai berikut :

1. Peraturan Menteri Agraria dan Tata Ruang/Kepala Badan Pertanahan Nasional Nomor 20 Tahun 2017 yang mengatur tentang jangka waktu surat kuasa membebankan hak tanggungan kredit mikro mempunyai banyak kelemahan dalam aturannya dan tidak memberikan perlindungan hukum terhadap salah satu pihak dalam hal ini kreditur, sebab jangka waktu yang terlalu lama tersebut statuts kreditur sebagai pemegang jaminan bukan lah sebagi kreditur preferen melainkan konkuren sebab surat kuasa membebankan hak tanggungan yang tidak akan ditingkat kan menjadi hak tanggungan hal ini tentu sangat tidak sesuai dengan hak preferen dari perbankan dan juga memberikan dampak kelalaian terhadap kreditur dalam memonitor kredit mikro jika terjadi wanprestasi dikemudian hari, dan dengan dikeluarkan peraturan ini juga sangat tidak sesuai dengan klausul surat kuasa membebankan hak tanggungan yang ada jika diterapkan pada surat kuasa membebankan hak tanggungan kredit mikro, dan akan berdampak pada notaris sebagai pejabat yang berwenang membuat akta tersebut, sebab jika notaris tidak mengetahui hal tersebut maka keotentikan akta yang dibuat oleh notaris menjadi hilang.

2. Fungsi notaris dalam mencegah jangka waktu surat kuasa membebankan hak tanggungan kredit mikro dapat dilakukan dengan memanfaatkan jabatannya sebagai salah satu penegak hukum dengan memberikan penyuluhan hukum sesuai dengan Undang-Undang Jabatan Notaris Nomor 2 Tahun 2014

\footnotetext{
26 Ibid.

${ }^{27}$ Yahya Harahap, Pengertian dan Dasar-Dasar Notaris, (Jakarta : Erlangga, 2007), hal 573.
} 
Pasal 15 huruf (e) dan notaris juga dapat menemukan klausul-klausul baru didalam aktanya jika terdapat klausul yang tidak sesuai dengan akta yang akan dibuat. Notaris memiliki peran penting dalam pemberian penyuluhan hukum dan kepada perbankan. Dengan dilaksanakannya penyuluhan hukum, maka Notaris dapat memberikan masukan kepada para pihak untuk melindungi kepentingannya dan menghindari potensi terjadinya masalah hukum yang terjadi di kemudian hari, sehingga para pihak (Debitur dan Kreditur) dapat mengetahui perbuatan hukum dan akibat hukum yang akan dihadapi, agar kepentingan para pihak dapat dilindungi. Dalam pembuatan akta dan pemberian penyuluhan hukum, Notaris harus memperhatikan asas kepastian hukum dan bertindak berdasarkan aturan hukum yang berlaku, sehingga akta yang dibuat oleh Notaris dapat dijadikan sebagai akta otentik dan alat bukti yang notariil bagi para pihak, sehingga penyuluhan hukum dan klausul-klausul baru yang diberikan oleh notaris dapat memberikan jalan tengah yang menguntungkan pihak kreditur maupun debitur.

\section{DAFTAR PUSTAKA}

\section{Buku}

Adrian Sutedi, Hukum Hak Tanggungan, Jakarta : Sinar Grafika, 2012

Bahder Johan Nasution, Metode Penelitian Ilmu Hukum, Bandung : CV. Mandar Maju, 2016 , Metode Penelitian Ilmu Hukum, Bandung: Mandar Maju, 2008

Habib Adjie, Kebatalan dan Pembatalan Akta Notaris, Bandung: PT. Refika Aditama, 2011 , Meneropong Khasanah Notaris dan PPAT Indonesia, (Bandung: PT. Citra Aditya Bakti, 2009

Hery Shietra, Praktik Hukum Jaminan Kebendaan, Bandung: Citra Aditya Bakti, 2016

Ishaq, Metode Penelitian Hukum Dan Penulisan Skripsi, Tesis Serta Disertasi, Bandung: Alfabeta, 2017

M. Khoidin, Dimensi Hukum Hak Tanggungan Atas Tanah, Yogyakarta: LaksBang, 2006

Mulyoto, Perjanjian; Tehnik Cara Membuat Dan Hukum Perjanjian Yang Harus Dikuasai, Yogyakarta: Cakrawala Media, 2012

Peter Mahmud Marzuki, Penelitian Hukum, Jakarta : Kencana, 2006

Soerjono Soekanto dan Sri Mamudji, Penelitian Hukum Normatif Suatu Tinjauan Singkat, Jakarta: Rajawali Pers, 2008

Subekti, Perjanjian; Hukum Perjanjian, Jakarta : Intermasa, 1990

Yahya Harahap, Pengertian dan Dasar-Dasar Notaris, Jakarta : Erlangga, 2007

\section{Peraturan Perundang-undangan}

Undang-Undang Nomor 4 Tahun 1996 Tentang Hak Tanggungan

Undang-undang nomor 5 Tahun 1960 Tentang Peraturan Dasar Pokok-Pokok Agraria.

Undang-Undang Nomor 30 tahun 2004 tentang Jabatan Notaris.

Undang-Undang Nomor 2 Tahun 2014 Tentang Perubahan atas Undang-Undang Nomor 30 Tahun 2004 Tentang Jabatan Notaris.

Undang-Undang Nomor 10 Tahun 1998 Tentang Perbankan.

Kitab Undang-undang Hukum Perdata.

Peraturan Menteri Agraria dan Tata Ruang/Kepala Badan Pertanahan Nasional Nomor 22 Tahun 2017 Tentang Jangka Waktu Surat Kuasa Membebankan Hak Tanggungan Kredit Tertentu.

Peraturan Menteri Agraria dan Tata Ruang/Kepala Badan Pertanahan Nasional Nomor 8 Tahun 2012 Bentuk Surat Kuasa Membebankan Hak Tanggungan.

\section{Internet/Jurnal/Tesis}

Abu Jusuf, Etika Jabatan Notaris Sebagai Profesi Hukum, Media Notariat, Nomor 2, 1999

Asep Setiawan, Analisis Yuridis Standar Prosedur Pelayanan Operasional (SPPOP) Notaris Dalam Pembuatan Akta Terkait Klausul Proteksi Diri Notaris Berdasarkan Pasal 15 AYAT (1) UndangUndang Nomor 2 Tahun 2014 Tentang Jabatan Notaris, Jurnal Akta Vol. 4, No. 1, 2017

Algadita F.R.S, Analisis Yuridis Penggunaan Surat Kuasa Membebankan Hak Tanggungan Bagi Kreditur Dalam Menangani Debitur Wanprestasi, Jurnal Private Law, 2014

Randy Putra Tama, Keberlakuan Surat Kuasa Membebankan Hak Tanggungan Yang Telah Habis Jangka Waktu, Jurnal Hukum Program Studi Magister Kenotariatan Universitas Sriwijaya, 2016 
Ahmad Zulfikar, Kekuatan Hukum Jangka Waktu Surat Kuasa Membebankan Hak Tanggungan Kredit Mikro pada Peraturan Menteri Agraria dan Tata Ruang/Kepala Badan Pertanahan Nasional Nomor 22 Tahun 2017

https://www.slideshare.net/FredyBagusKusumaning Yandi/teori-hukum-dan-penemuan-hukum-notaris-drachmad-sulchan 